\title{
併用継手の力学性状に関する実験的研究 \\ EXPERIMENTAL STUDY ON THE BEHAVIOR OF COMBINED JOINTS USING FILLET WELDINGS AND HIGH STRENGTH BOLTS
}

\author{
增田浩志*, 神保秀治**, 田中淳夫***, 植木 隆司**** \\ Hiroshi MASUDA, Hideharu JINBO, Atsuo TANAKA \\ and Takashi UEKI
}

\begin{abstract}
The static characteristics of the combined joints using fillet weldings and high strength bolts are experimentally investigated in order to check the possibility of accumulation of the strength of each connecting element. In this study $50 \mathrm{~mm}$ long fillet welding with $5 \mathrm{~mm}$ size is decided as an unit of welding and M16 or M20 (S10T) high strength bolt is unit of bolt. Combinations of 0 3 units of each connecting element are selected as test specimen. Tottally 76 specimens were tested. It becomes clear that the maximum strength of the combined joints using fillet weldings and high strength bolts is $5-15 \%$ smaller than the accumulated value of the slip strength of high strength bolts and the maximum strength of fillet weldings. And the maximum design strength, of combined joints using fillet weldings and high strength bolts, which is calculated by nominal strength has enough safety.
\end{abstract}

keywords : combined joints, front fillet welding, side fillet welding, high strength bolts, maximum strength 併用継手、前面隅肉溶接、側面隅肉溶接、高力ボルト、最大耐力

1. 序

高力ボルトと隅肉溶接を併用した継手についての実験は過去に日 本建築学会の接合小委員会によってかなり統計的な研究が行われて おりり、そこでは、各種併用継手の力学性状、累加耐力の成立の有無 の条件等が検討されている。この研究成果は基本的に現在でも同様 の継手に十分通用可能であると思われるが、この研究が行われてか ら既に約 30 年が経過しており、現在では高力ボルトの強度レベル、 摩擦面の表面処理方法、溶接継目の力学性能などが上記の研究が行 われた時期のものとかなりと異なってきている。従って、現時点で 一般に用いられている接合形式について併用継手の力学性状を改め て検討しておく必要がある。このような状況を背景として本研究は、 現状における併用継手の力学性状を再検討することを目的として、 実験を行い考察したものである。表 1 に前記接合小委員会の研究と 本研究における接合部の概要をまとめた。

\section{2. 実験の概要}

本研究で用いた試験体の基本的形状、寸法等の概要を図 1 に示す。 試験体は、中板の両側から添板で接合する形式であり、基本的には、 接合部の降伏耐力が母材ないし添板の有効断面の降伏耐力より小さ くなるように設計している。母材は板厚 $25 \mathrm{~mm} 、$ 板幅 $140 \mathrm{~mm} 、$ 添板は板
表 1 接合部概要

\begin{tabular}{|c|c|c|}
\hline$m$ & 接合小委員会 & 本研究 \\
\hline 母材 & SM50A & SM490A \\
\hline 摩撩面仕上げ & 赤さび仕上げ & グリットブラススト级理 \\
\hline 高カボルト & F9T・ウィット系ねじ & S10T・メートルねじ \\
\hline 溶着金属 & $\begin{array}{c}\text { JIS Z } 3212 \text { D5026 } \\
\text { 手溶接 } \\
\text { 低水素系高張力鎆用 }\end{array}$ & $\begin{array}{c}\text { JIS Z } 3312 \text { YGW11 } \\
\text { 半自動溶接 } \\
\text { 高張力鎆用ソツッドワイヤ }\end{array}$ \\
\hline
\end{tabular}

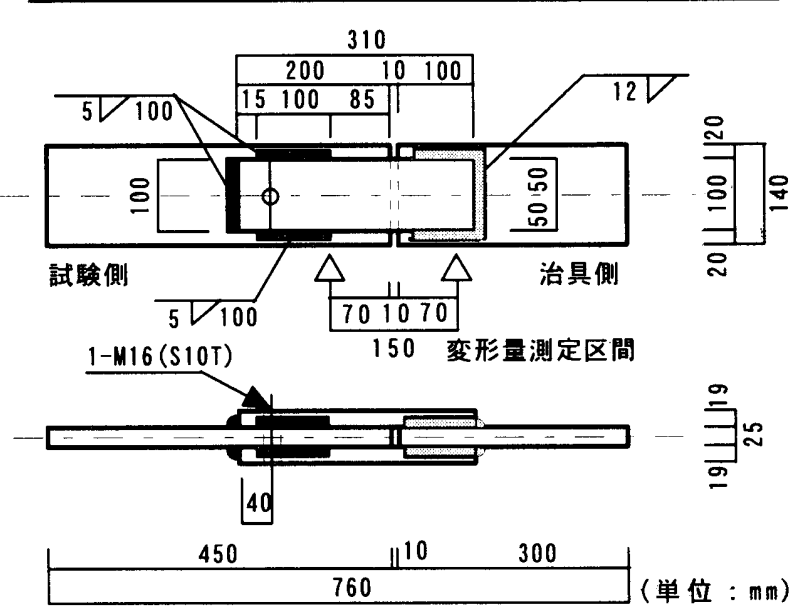

図1 試験体概要及び変形量測定区間

\footnotetext{
* 宇都宫大学工学部建設学科 助手・博士 (工学)

**巴コーポレーション エ修

*** 宇都宮大学工学部建設学科 教授 $\cdot$ 工博

**** 巴コーポレーション 工.博
}

Research Assoc., Dept. of Architecture, Utsunomiya University, M. Eng. Tomoe Corporation, M. Eng.

Prof., Dept. of Architecture, Utsunomiya University, Dr. Eng.

Tomoe Corporation, Dr. Eng. 
厚 $19 \mathrm{~mm}$ 、板幅 $100 \mathrm{~mm}$ の鋼板を用いている。試験部分の隅肉溶接のサ イズは全て $5 \mathrm{~mm}$ とし、溶接の余盛を削り、のど厚を一定に仕上げて いる。溶接の長さは $50 \mathrm{~mm}$ を単位長とし、溶接端部が垂直となるよう に処理している。これより、本実験において隅肉溶接の有効長さは 溶接長さそのものとして考えることができる。前面隅肉溶接は表裏 2 ビードで 1 単位となり、側面隅肉溶接は表裹、左右 4 ビードで 1 単位である。また治具側については、脚長 $12 \mathrm{~mm}$ または $16 \mathrm{~mm} の$ 隅肉溶 接で添板の 3 辺を連続して溶接している。

高力ボルト接合部の摩擦面は、すべてグリッドブラスト処理とし た。試験体組立に先立ち、全試験体について表面粗さを測定してお り、表面粗さの平均値は74.3 $\mu \mathrm{mRy}$ (標準偏差: 7.14、変動係数:0.096) であった。

使用した高力ボルトは、トルシア形高力ボルト(S10T) とし、ボル トの呼び径はM16およびM20である。孔径は公称径＋2mm とした。ボ ルトの初期導入張力はボルト締付試験の結果、M16では $113 \mathrm{kN} 、 M 20$ では $181 \mathrm{kN}$ の值が得られた (表 6 参照)。ボルト配置はM16、M20 とも

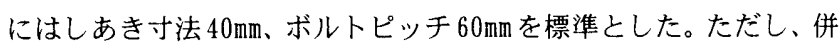
用継手はトラスの弦材と斜材の接合部や筋かい材の材端接合部など 接合部の長さが限定される部分への使用が想定され、この場合は高 カボルトのはしあき寸法およびボルトピッチを小さくすることが有 効であるため、M20のボルトについて標準配置の他に最小はしあきか つ最小ピッチ配置を計画した。最小はしあき最小ピッチ配置ははし あき寸法が $25 \mathrm{~mm} 、$ ボルトピッチが $50 \mathrm{~mm}$ である。

隅肉溶接と高力ボルトの併用継手試験体では、ボルト締めを行っ た後に溶接を行った。溶接は炭酸ガスシールドアーク溶接で行い、 溶接工はすべて同一人物が行った。

試験体の組立および実験に先立ち、溶接長、溶接のど厚、溶接表 面加工状態の実測および観測を行った。試験体に用いた各材料は下 記のとおりである。

\section{表2 試験体一覧}

\begin{tabular}{c|c|c|c}
\hline \multirow{2}{*}{ 試験体名称 } & \multicolumn{3}{|c}{ 巣位数 } \\
\cline { 2 - 4 } & B & $\mathrm{F}$ & $\mathrm{S}$ \\
\hline BOF1S0 & 0 & 1 & 0 \\
\hline BOF1.5SO & 0 & 1.5 & 0 \\
\hline BOF2S0 & 0 & 2 & 0 \\
\hline BOFOS1 & 0 & 0 & 1 \\
\hline BOFOS2 & 0 & 0 & 2 \\
\hline BOFOS3 & 0 & 0 & 3 \\
\hline BOF2S1 & 0 & 2 & 1 \\
\hline BOF1S1 & 0 & 1 & 1 \\
\hline BOF2S2 & 0 & 2 & 2 \\
\hline BOF1S2 & 0 & 1 & 2 \\
\hline B1FOSO-16 & 1 & 0 & 0 \\
\hline B1FOSO-16 & 1 & 0 & 0 \\
\hline B2FOSO-16 & 2 & 0 & 0 \\
\hline B2FOSO-16 & 2 & 0 & 0 \\
\hline B3FOSO-16 & 3 & 0 & 0 \\
\hline B3FOSO-16 & 3 & 0 & 0 \\
\hline B1FOSO-20 & 1 & 0 & 0 \\
\hline B1FOSO-20 & 1 & 0 & 0 \\
\hline B2FOSO-20 & 2 & 0 & 0 \\
\hline B2FOSO-20 & 2 & 0 & 0 \\
\hline B3FOSO-20 & 3 & 0 & 0 \\
\hline B3FOSO-20 & 3 & 0 & 0 \\
\hline B1FOSO-H & 1 & 0 & 0 \\
\hline B2FOSO-H & 2 & 0 & 0 \\
\hline B3FOSO-H & 3 & 0 & 0 \\
\hline & &
\end{tabular}

\begin{tabular}{|c|c|c|c|c|c|c|c|}
\hline \multirow{2}{*}{ 試験体名称 } & \multicolumn{3}{|c|}{ 単位数 } & \multirow{2}{*}{ 試験体名称 } & \multicolumn{3}{|c|}{ 単位数 } \\
\hline & $B$ & $F$ & s & & $B$ & $F$ & $S$ \\
\hline $150-16$ & 1 & 1 & 0 & B1F0S1-H & 1 & 0 & 1 \\
\hline B1F2S0-16 & 1 & 2 & 0 & B1F0S2-H & 1 & 0 & 2 \\
\hline $\mathrm{B} 2 \mathrm{~F} 1 \mathrm{SO}-16$ & 2 & 1 & 0 & B2FOS $1-\mathrm{H}$ & 2 & 0 & 1 \\
\hline $\mathrm{B} 2 \mathrm{~F} 2 \mathrm{~S} 0-16$ & 2 & 2 & 0 & $\mathrm{~B} 2 \mathrm{FOS} 2-\mathrm{H}$ & 2 & 0 & 2 \\
\hline B1F1S0-20 & - & 1 & 0 & B3FOS1-H & 3 & 0 & 1 \\
\hline $\mathrm{B} 1 \mathrm{~F} 2 \mathrm{~S} 0-20$ & 1 & 2 & 0 & B3FOS2-H & 3 & 0 & 2 \\
\hline B2F1S0-20 & 2 & 1 & 0 & B1F2S1-16 & 1 & 2 & 1 \\
\hline $\mathrm{B} 2 \mathrm{~F} 2 \mathrm{SO}-20$ & 2 & 2 & 0 & B1F1S1-16 & 1 & 1 & 1 \\
\hline B1F0S1-16 & 1 & 0 & 1 & B1F2S2-16 & 1 & 2 & 2 \\
\hline B1F0S2-16 & 1 & 0 & 2 & $32-16$ & 1 & 1 & 2 \\
\hline B1FOS3-16 & 1 & 0 & 3 & $\mathrm{~B} 2 \mathrm{~F} 2 \mathrm{~S} 1-16$ & 2 & 2 & 1 \\
\hline B2FOS1-16 & 2 & 0 & 1 & B2F1S1-16 & 2 & 1 & \\
\hline $\mathrm{B} 2 \mathrm{FOS} 2-16$ & 2 & 0 & 2 & $\mathrm{~B} 2 \mathrm{~F} 2 \mathrm{~S} 2-16$ & 2 & 2 & 2 \\
\hline B2F0S3-16 & 2 & 0 & 3 & $\mathrm{~B} 2 \mathrm{~F} 1 \mathrm{~S} 2-16$ & 2 & 1 & 2 \\
\hline B3FOS $1-16$ & 3 & 0 & 1 & $\mathrm{~B} 1 \mathrm{~F} 2 \mathrm{~S} 1-20$ & 1 & 2 & \\
\hline B3FOS2-16 & 3 & 0 & 2 & B1F1S1-20 & 1 & 1 & 1 \\
\hline B3FOS3-16 & 3 & 0 & 3 & B1F2S2-20 & 1 & 2 & 2 \\
\hline B1FOS $1-20$ & 1 & 0 & 1 & B1F1S2-20 & 1 & 1 & 2 \\
\hline B1FOS2-20 & \begin{tabular}{|l|}
1 \\
\end{tabular} & 0 & 2 & B2F2S1-20 & 2 & 2 & 1 \\
\hline B1F0S3-20 & 1 & 0 & 3 & $\mathrm{~B} 2 \mathrm{~F} 1 \mathrm{~S} 1-20$ & 2 & 1 & 1 \\
\hline B2F0S1-20 & 2 & 0 & 1 & $\mathrm{~B} 2 \mathrm{~F} 2 \mathrm{~S} 2-20$ & 2 & 2 & 2 \\
\hline B2FOS2-20 & 2 & 0 & 2 & $\mathrm{~B} 2 \mathrm{~F} 1 \mathrm{~S} 2-20$ & 2 & 1 & 2 \\
\hline $\mathrm{B} 2 \mathrm{FOS} 3-20$ & 2 & 0 & 3 & $\mathrm{~B} 1 \mathrm{~F} 2 \mathrm{~S} 1-\mathrm{H}$ & 1 & 2 & 1 \\
\hline B3FOS $1-20$ & 3 & 0 & 1 & B1F2S2-H & 1 & 2 & 2 \\
\hline B3F0S2-20 & 3 & 0 & 2 & $\mathrm{~B} 2 \mathrm{~F} 2 \mathrm{~S} 2-\mathrm{H}$ & 2 & 2 & 2 \\
\hline B3FOS $3-20$ & 3 & 0 & & & & & \\
\hline
\end{tabular}

母材：SM490A (添板 : PL19 (幅 100mm)、中板 : PL25 (幅 140mm)) 高力ボルト：S10T (呼び径 M16、M20)

溶接棒: YGW11 (490N/mm²級高張力鋼用・ $\mathrm{CO}_{2}$ 用)

本研究で併用継手の力学性状を確認するために用意した試験体の

一覧を表 2 に示す。試験体の総数は76 体である。

\section{3. 試験体名称}

併用継手試験体の名称は「BiFjSk-n」で表記する。その意味は以 下のとおりである。

$\mathrm{Bi}$ : 高力ボルト (1 本を 1 単位とし、 $\mathrm{i}$ 単位用いる)

$\mathrm{Fj}$ : 前面隅肉溶接(ビード基本長 $50 \mathrm{~mm}$ とし、表裹合わせて 2 ビードを 1 単位とし、 $j$ 単位用いる)

Sk：側面隅肉溶接（ビード基本長 $50 \mathrm{~mm}$ とし、表裏と左右合わせて 4 ビードを 1 単位とし、 $\mathrm{k}$ 単位用いる)

$\mathrm{n}$ : 高力ボルトの呼び径および高力ボルト配置 (M1 6 の標準配置を16、 M20 の標準配置を20、M20 の最小はしあき最小ピッチ配置をH と 表記する。）

例えば、B1F2S2-16の表示は高力ボルト1本、前面隅肉溶接 2単位、 側面隅肉溶接 2 単位の併用継手で、高力ボルトは呼び径M16で標準配 置とした試験体を表す。

\section{4. 載荷と測定}

載荷はアムスラ一型引張試験機により破断が生じるまで単調引張 とした。すべり荷重、最大荷重、破断荷重については、試験機から の読みとり值と試験機連動の計測器による測定を平行して行った。 変形量については、試験体の左右に取り付けた変位計 2 台により測 定した。変形量測定区間は全ての試験体において図 1 に示すもので あり、その長さは $150 \mathrm{~mm}$ である。

\section{5. 接合部構成要素の実䀫結果}

\section{1. 材料}

\section{1 .1 母材}

実験に用いた母材はSM490AのPL19、PL25の2種類でありそれぞれ の板厚のものにつきJIS Z 2201 (金属材料引張試験方法)による1A号 試験片により引張試験を行った。

引張試験結果およびミルシートによる化学成分を表 3 に示す。

\section{1 .2 溶着金属}

試験片は、JIS Z 2201(金属材料引張試験方法)に規定されたJIS 10 号試験片で試験体の隅肉溶接と同じ溶接条件で作られた溶着金属 中より切り出したものである。これを 3 本作成した。試験結果を表 4 に、併用継手試験体作成時の溶接条件を表 5 に示す。

\section{1 .3 高力ボルト}

高力ボルトはトルシア形高力ボルト (S10T) M1 6 およびM20を用い た。各 5 本のボルトによるボルト締付け試験結果を表 6 に示す。

\section{2 接合要素単体の基本的性質}

\section{2 .1 高力ボルト継手}

本実験に㧍ける高力ボルト継手の実験結果を表 7 によめた。す ベての試験体についてすべり係数は安定した値が得られている。

M1 6 の高力ボルトを用いた場合の 1 本当たりすべり耐力の平均は $166 \mathrm{kN}$ 、最大耐力は $275 \mathrm{kN} 、 M 20$ の場合はそれぞれ $244 \mathrm{kN} 、 416 \mathrm{kN}$ であ 
表3母材の素材試験結果及び化学成分

\begin{tabular}{|c|c|c|c|c|c|c|c|c|c|c|c|}
\hline \multirow{2}{*}{\multicolumn{2}{|c|}{ 素村試験片名称 }} & \multirow{2}{*}{\begin{tabular}{|l|} 
降伏応力住 \\
$\sigma \mathrm{y}\left(\mathrm{N} / \mathrm{mm}^{2}\right.$
\end{tabular}} & \multirow{2}{*}{\multicolumn{2}{|c|}{\begin{tabular}{|l|} 
最大応力度 \\
$\sigma u\left(\mathrm{~N} / \mathrm{mm}^{2}\right)$ \\
\end{tabular}}} & \multirow{2}{*}{\multicolumn{2}{|c|}{ 伸び(\%) }} & \multicolumn{5}{|c|}{ 化学成分 $(\%)$} \\
\hline & & & & & & & $\mathrm{c}$ & $\mathrm{Si}$ & $\mathrm{Mn}$ & $\mathbf{P}$ & $s$ \\
\hline \multicolumn{2}{|l|}{ PL19 } & 389 & \multicolumn{2}{|c|}{539} & \multicolumn{2}{|c|}{27.6} & & \multirow{2}{*}{\begin{tabular}{|l|}
0.460 \\
0.280
\end{tabular}} & 1.42 & 0.018 & \multirow{2}{*}{\begin{tabular}{|l|l|}
0.050 \\
0.050
\end{tabular}} \\
\hline \multicolumn{2}{|l|}{ PL25 } & 444 & \multicolumn{2}{|c|}{533} & 29.3 & & \begin{tabular}{|l|l|}
0.100 \\
\end{tabular} & & \begin{tabular}{l|l|}
0.280 & 1.51 \\
\end{tabular} & 0.010 & \\
\hline \multicolumn{12}{|c|}{ 表4 溶着金属引張試験 } \\
\hline \multicolumn{2}{|c|}{ 素材試験片名称 } & \multicolumn{4}{|c|}{ 降伏応力度 $\sigma \mathrm{y}\left(\mathrm{N} / \mathrm{mm}^{2}\right)$} & \multicolumn{4}{|c|}{ 最大俯力度 $\sigma \mathrm{u}\left(\mathrm{N} / \mathrm{mm}^{2}\right)$} & \multicolumn{2}{|c|}{ 伸び(x) } \\
\hline \multicolumn{2}{|c|}{ 溶着金属その1 } & \multicolumn{4}{|c|}{412} & \multicolumn{4}{|c|}{527} & \multicolumn{2}{|r|}{32.0} \\
\hline \multicolumn{2}{|c|}{ 溶着金属その2 } & \multirow{2}{*}{\multicolumn{4}{|c|}{$\frac{392}{421}$}} & \multicolumn{4}{|c|}{495} & \multicolumn{2}{|c|}{37.5} \\
\hline \multicolumn{2}{|c|}{ 溶着金属その3 } & & & & & & & 514 & & & 38.4 \\
\hline 平均他 & & \multicolumn{4}{|c|}{408} & \multicolumn{4}{|c|}{512} & & 36.0 \\
\hline \multicolumn{3}{|c|}{ 表5 溶接条件 } & \multicolumn{9}{|c|}{ 表6 高力ボルト締付け試験結果 } \\
\hline 速度 & $30 \mathrm{~cm}$ & $/ \min$ & 早級及び & & & 紻め1 & 付け䡒 & 由カの制 & 剘定値 $(\mathrm{k})$ & & \\
\hline & & & 寸法 & 1 & 2 & 3 & 4 & 5 & 平均値 & 変動何 & 保数 \\
\hline 㫣在 & $27 \sim$ & $28 \mathrm{~V}$ & S10T & $110 \mid$ & 111 & 107 & 116 & $\mid 122$ & 113 & 0.05 & 051 \\
\hline 電流 & 150 & & $116 \times 90$ & & & & & & & & \\
\hline パス間温度 & $300^{\circ}$ & 前後 & $\begin{array}{l}S 10 \mathrm{~T} \\
\text { M20 } \times 95\end{array}$ & 180 & 175 & 183 & 184 & 179 & 181 & 0.01 & 019 \\
\hline
\end{tabular}

表7 高カボルト継手実験結果

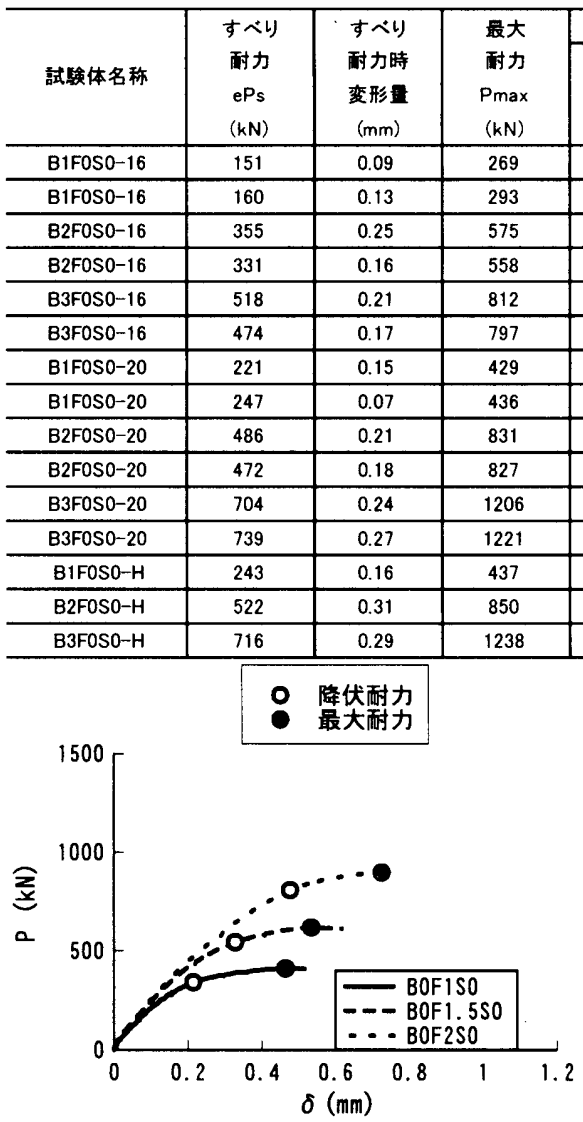

（a）前面隅肉溶接継手

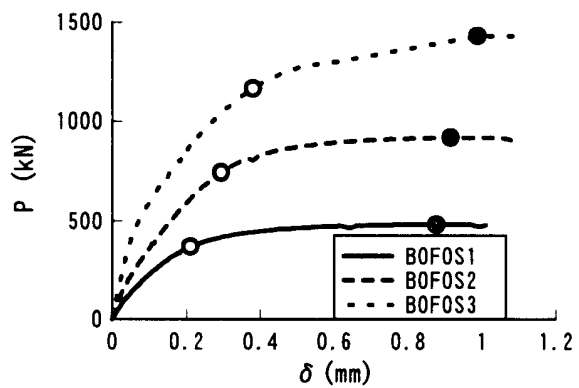

(b) 側面隅肉溶接継手

図2 荷重一変形関係
表8 前面隅肉溶接継手実験結果

\begin{tabular}{|c|c|c|c|c|c|c|c|}
\hline \multirow[b]{2}{*}{ 試験体名称 } & \multirow[b]{2}{*}{$\begin{array}{l}\text { ePwfy } \\
(\mathrm{kN})\end{array}$} & \multirow[b]{2}{*}{$\begin{array}{l}\text { ePwfu } \\
(\mathrm{kN})\end{array}$} & \multicolumn{2}{|c|}{ 変形量 } & \multirow[b]{2}{*}{$\begin{array}{c}\text { Af } \\
\left(\mathrm{cm}^{2}\right)\end{array}$} & \multirow[b]{2}{*}{ kwty } & \multirow[b]{2}{*}{ kwfu } \\
\hline & & & $\begin{array}{c}\text { ePwfy時 } \\
\text { (mm) }\end{array}$ & $\begin{array}{c}\text { ePwfu時 } \\
\text { (mm) }\end{array}$ & & & \\
\hline BOF1SO & 345 & 413 & 0.22 & 0.48 & 4.81 & 3.11 & 2.84 \\
\hline BOF $1.5 \mathrm{~S} 0$ & 546 & 619 & 0.33 & 0.55 & 6.48 & 3.66 & 3.17 \\
\hline BOF2SO & 811 & 900 & 0.48 & 0.73 & 9.11 & 3.87 & 3.28 \\
\hline
\end{tabular}

表9 側面隅肉溶接継手実験結果

\begin{tabular}{|c|c|c|c|c|c|c|c|}
\hline \multirow[b]{2}{*}{ 試駼体名称 } & \multirow[b]{2}{*}{$\begin{array}{l}\text { ePwsy } \\
(\mathrm{kN})\end{array}$} & \multirow{2}{*}{$\begin{array}{l}\text { ePwsu } \\
\text { (kN) }\end{array}$} & \multicolumn{2}{|c|}{ 変形贯 } & \multirow{2}{*}{$\begin{array}{c}\text { As } \\
\left(\mathrm{cm}^{2}\right)\end{array}$} & \multirow[b]{2}{*}{ kwsy } & \multirow[b]{2}{*}{ kwsu } \\
\hline & & & $\begin{array}{c}\text { ePwsy時 } \\
(\mathrm{mm})\end{array}$ & $\begin{array}{c}\text { ePwsu時 } \\
(\mathrm{mm})\end{array}$ & & & \\
\hline BOFOS1 & 372 & 480 & 0.22 & 0.89 & 8.30 & 1.94 & 1.92 \\
\hline BOFOS2 & 754 & 918 & 0.30 & 0.94 & 16.8 & 1.94 & 1.82 \\
\hline BOFOS3 & 1179 & 1431 & 0.39 & 0.99 & 25.7 & 1.99 & 1.85 \\
\hline
\end{tabular}

表10 前面隅肉溶接継手追加実験結果

\begin{tabular}{|c|c|c|c|c|c|c|c|c|}
\hline \multirow[b]{2}{*}{ 試験体名称 } & \multirow{2}{*}{$\begin{array}{c}\text { 溶接 } \\
\text { サイス } \\
(\mathrm{mm}) \\
\end{array}$} & \multirow[b]{2}{*}{$\begin{array}{l}\text { ePwfy } \\
(\mathrm{kN})\end{array}$} & \multirow[b]{2}{*}{$\begin{array}{l}\text { ePwfu } \\
(\mathrm{kN})\end{array}$} & \multicolumn{2}{|c|}{ 变形量 } & \multirow[b]{2}{*}{$\begin{array}{c}\text { Af } \\
\left(\mathrm{cm}^{2}\right)\end{array}$} & \multirow[b]{2}{*}{ kwfy } & \multirow[b]{2}{*}{ kwfu } \\
\hline & & & & $\begin{array}{c}\text { ePwfy時 } \\
\text { (mm) }\end{array}$ & $\begin{array}{c}\text { ePwfu時 } \\
\text { (mm) }\end{array}$ & & & \\
\hline BOF1S0-s5 & 5 & 303 & 357. & 0.19 & 0.37 & 4.52 & 3.19 & 2.67 \\
\hline $\mathrm{BOF} 2 \mathrm{SO}-\mathrm{s} 5$ & 5 & 512 & 647 & 0.24 & 0.58 & 7.97 & 3.06 & 2.75 \\
\hline BOF1SO-s 10 & 10 & 425 & 596 & 0.25 & 1.14 & 7.88 & 2.56 & 2.56 \\
\hline $\mathrm{BOF} 2 \mathrm{SO}-\mathrm{s} 10$ & 10 & 815 & 1142 & 0.44 & 1.69 & 16.1 & 2.40 & 2.39 \\
\hline $\mathrm{BOF} 1 \mathrm{SO}-\mathrm{s} 15$ & 15 & 457 & 696 & 0.25 & 1.75 & 11.9 & 1.82 & 1.97 \\
\hline BOF $2 \mathrm{SO}-\mathrm{s} 15$ & 15 & 913 & 1395 & 0.46 & 6.18 & 23.4 & $i .86$ & 2.02 \\
\hline
\end{tabular}

表11 側面隅肉溶接継手追加実験結果

\begin{tabular}{|c|c|c|c|c|c|c|c|c|}
\hline \multirow[b]{2}{*}{ 試験体名称 } & \multirow{2}{*}{$\begin{array}{c}\begin{array}{c}\text { 溶接 } \\
\text { サイス } \\
(\mathrm{mm})\end{array} \\
\end{array}$} & \multirow[b]{2}{*}{$\begin{array}{l}\text { ePwsy } \\
(\mathrm{kN})\end{array}$} & \multirow{2}{*}{$\begin{array}{l}\text { ePwsu } \\
(\mathrm{kN})\end{array}$} & \multicolumn{2}{|c|}{ 変形量 } & \multirow{2}{*}{$\begin{array}{c}\text { As } \\
\left(\mathrm{cm}^{2}\right) \\
\end{array}$} & \multirow[b]{2}{*}{ kwsy } & \multirow[b]{2}{*}{ kwsu } \\
\hline & & & & $\begin{array}{c}\text { ePwsy時 } \\
(\mathrm{mm})\end{array}$ & $\begin{array}{c}\text { ePwsu時 } \\
(\mathrm{mm})\end{array}$ & & & \\
\hline BOFOS1-s5 & 5 & 338 & 432 & 0.15 & 1.12 & 9.33 & 1.72 & 1.57 \\
\hline BOF0S2-s5 & 5 & 672 & 917 & 0.26 & 1.23 & 17.09 & 1.87 & 1.82 \\
\hline BOFOS1-s 10 & 10 & 499 & 746 & 0.24 & 2.69 & 17.94 & 1.32 & 1.41 \\
\hline BOFOS $2-s 10$ & 10 & 973 & 1464 & 0.16 & 5.59 & 32.22 & 1.44 & 1.54 \\
\hline BOFOS $1-s 15$ & 15 & 517 & 917 & 0.25 & 6.13 & 23.81 & 1.03 & 1.30 \\
\hline BOFOS1.6-s 15 & 15 & 1012 & 1495 & 0.45 & 8.47 & 37.27 & 1.29 & 1.36 \\
\hline
\end{tabular}

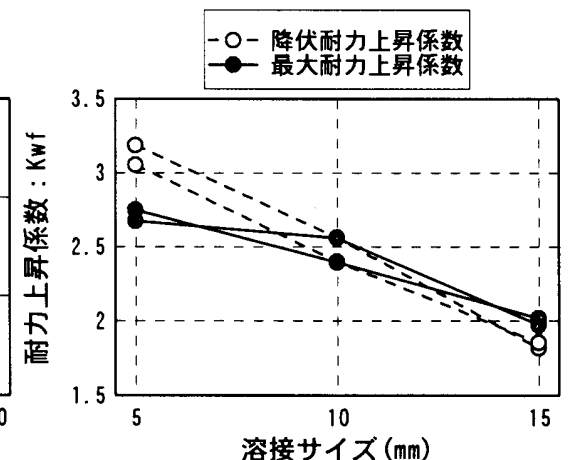

(a) 前面隅肉溶接継手

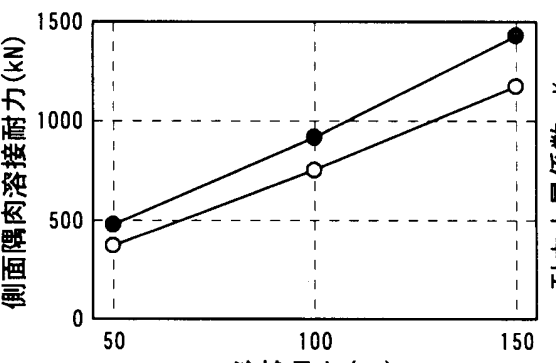

溶接長さ $(\mathrm{mm})$

(b) 側面隅肉溶接継手

図3 隅肉溶接耐カー溶接長さ関係

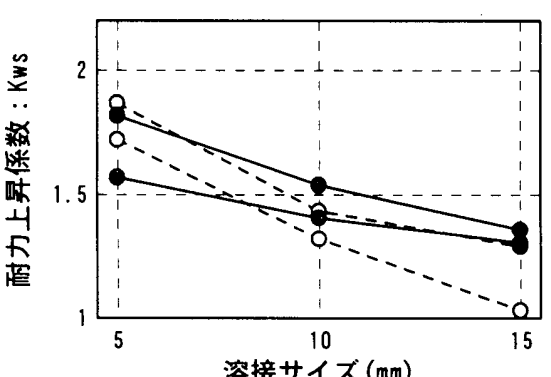

(b) 側面隅肉溶接継手
図4 耐力上昇係数一溶接サイズ関係 
ろ。

\section{2 .2 䧉肉溶接継手}

本実験における前面隅肉溶接のみの継手および側面隅肉溶接のみ

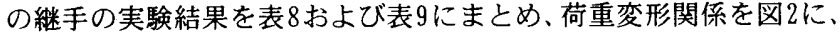
各隅肉溶接継手の最大耐力および降伏耐力と溶接長さの関係を図 3 に示す。表中に示した前面隅肉溶接、側面隅肉溶接の降伏耐力 (ePwfy,ePwsy) 嗬重変形関係における接線剛性が初期剛性の $1 / 3 に$ なるときの荷重であり、図 2 に○で示す。降伏耐力上昇係数 $(\kappa v 1 \%$ $\kappa$ vsy $)$ 、最大耐力上昇係数 $(\kappa$ v $/ u 、 \kappa$ wu $)$ は以下の (1)、(2) 式で求めた 值である。

前面隅肉溶接の耐力上昇係数

$\kappa: f y=\frac{e P w f y}{A f \cdot \sigma y / \sqrt{3}} \quad$ (1a) $\quad \kappa w f u=\frac{e P w f u}{A f \cdot \sigma u / \sqrt{3}}$

側面隅肉溶接の耐力上昇係数

$$
\kappa_{\text {wsy }}=\frac{\mathrm{ePwsy}}{\mathrm{As} \cdot \sigma \mathrm{y} / \sqrt{3}} \quad \text { (2a) } \quad \kappa_{\text {wsu }}=\frac{\mathrm{ePwsu}}{\mathrm{As} \cdot \sigma \mathrm{u} / \sqrt{3}}
$$

ePw fy, ePwfu : 前面隅肉溶接の降伏耐力および最大耐力 $(\mathrm{kN})$

ePwsy, ePwsu：側面隅肉溶接の降伏耐力および最大耐力 (kN)

Af : 前面隅肉溶接の破断部分面積 (実測値) ( $\left.\mathrm{cm}^{2}\right)$

As：側面隅肉溶接の破断部分面積 (実測值) $\left(\mathrm{cm}^{2}\right)$

$\sigma \mathrm{y}:$ 溶接金属の降伏強さ $\left(\mathrm{N} / \mathrm{mm}^{2}\right)$

$\sigma \mathrm{u}:$ 溶接金属の引張強さ $\left(\mathrm{N} / \mathrm{mm}^{2}\right)$

本実験において 。は溶着金属と母材のそれぞれの降伏強さないし 引張強さの平均としている $\left(\sigma \mathrm{y}=(408+389) / 2=399\left(\mathrm{~N} / \mathrm{mm}^{2}\right) 、 \sigma \mathrm{u}=\right.$ $\left.(512+533) / 2=523\left(\mathrm{~N} / \mathrm{mm}^{2}\right)\right)$ 。また、隅肉溶接の破断角度は、隅肉 溶接のみの継手に限らずすべての試験体において前面隅肉溶接では $20^{\circ} \sim 25^{\circ}$ 、側面隅肉溶接ではほぼ $45^{\circ}$ であり、その破断角度を 図 5 に示す。隅肉溶接の破断面積は破断後の溶接幅を実測しそれに 溶接長さを乗じて求めた。溶接破断部の幅は隅肉溶接の耐力算定に 用いる理論のど厚の前面隅肉溶接で 1.20 倍、側面隅肉溶接で 1.18 倍 程度であった。

図3よりこの溶接長さの範囲において、隅肉溶接継手の最大耐力、 降伏耐力と溶接長さの間にはほぼ比例関係が成り立ち、前面隅肉溶 接、側面隅肉溶接ともに溶接長さに関する寸法効果による影響はな いものと考えられる。従って、前面隅肉溶接、側面隅肉溶接の 1 単 位当たりの降伏耐力、最大耐力は全試験体の平均值をとることとし、 それぞれ $378 \mathrm{kN} 、 429 \mathrm{kN}$ および $384 \mathrm{kN} 、 472 \mathrm{kN}$ とする。

最大耐力上昇係数については日本建築学会の「鋼構造限界状態設 計指針・同解説」3)に示されている実験值 (前面隅肉溶接で2.06、側 面隅肉溶接で1.35)に対しかなり高い値となっている。これは、本隅 肉溶接がJIS Z 3312 の高張力鋼用ソリッドワイヤ(YGW11)を使用し た比較的大きな電流による炭酸ガスシールドアーク溶接であるため に溶接サイズの $5 \mathrm{~mm}$ に対し溶け込み量の割合が大きいことと、母材 板厚 $25 \mathrm{~mm}$ 、添板板厚 $19 \mathrm{~mm}$ に対し隅肉溶接のサイズが $5 \mathrm{~mm}$ と極端に小
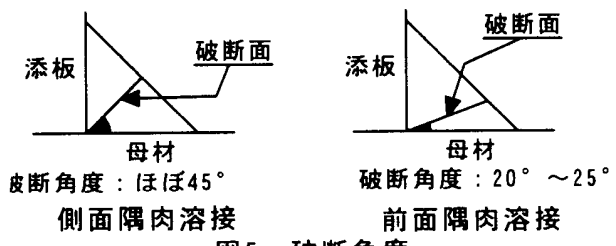

破断角度
さいため、溶接金属の硬化の度合いが激しかったことによるものと 考えられる。そこで、この点を確認するために同じ板厚の試験体で 溶接サイズを $5 \mathrm{~mm} 、 10 \mathrm{~mm}, 15 \mathrm{~mm}$ と変化させた追加実験を行い、耐力上 昇係数を検討した。その結果を表 $10 、 11$ に示し、耐力上昇倸数と溶 接サイズの関係を図 4 に示す。この結果より上述の事情が裏付けら れたことになり、一般的なサイズである母材または添板の厚さの 0.7 倍程度の隅肉溶接を用いた場合には最大耐力上昇係数は従来の実験 結果とほぼ同等のものとなることが判る。なお、追加実験における 溶接サイズ $5 \mathrm{~mm}$ の值が本実験の試験体の值より幾分小さくなってい るが、この点は本実験の試験体の表面がグリットブラスト処理で あったのに対し追加実験の試験体の表面がミルスケールのついたま まの状態であり、その結果母材への溶け込み量に差が生じたためで あると考えられる。隅肉溶接の変形能についてみると、最大変形能 力は前面隅肉溶接継手で $0.5 \sim 0.7 \mathrm{~mm}$ 、側面隅肉溶接で $0.9 \sim 1.2 \mathrm{~mm}$ であった。これらの值は高力ボルト継手におけるすべり量以下であ る。

\section{6. 併用継手の実倹結果}

\section{1 併用隅肉溶接継手}

本実験における前面隅肉溶接と側面隅肉溶接との併用隅肉溶接継 手の引張実験結果を表 12 にまとめ、荷重変形関係を図 6 に示す。

\section{2 高力ボルトと隅肉溶接の併用継手}

本実験における高力ボルトと隅肉溶接の併用継手の引張実験結果 を表 13 にまとめ、M20ボルト(標準配置)を用いた試験体の荷重一変 形関係を図7に示す。M16を用いた試験体およびM200最小はしあき 最小ピッチ配置の試験体についてはM20の標準配置の試験体とほほ 同じ挙動を示したので荷重変形関係は省いている。

\section{7. 考察}

\section{1 接合部の挙動}

図7に示した併用継手の荷重変形関係を見ると、すべての試験体 について隅肉溶接継目の破断により最大耐力を示すが、併用継手の

表 12 併用隅肉溶接継手

\begin{tabular}{|c|c|c|c|c|c|c|c|c|c|c|}
\hline \multirow{3}{*}{ 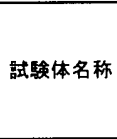 } & \multicolumn{2}{|c|}{ 実験結果 } & \multicolumn{8}{|c|}{ 君察結果 } \\
\hline & \multirow{2}{*}{\begin{tabular}{c|} 
柇力 \\
Pmax \\
$(\mathrm{KN})$ \\
\end{tabular}} & \multirow{2}{*}{\begin{tabular}{|c|} 
変形量 \\
$\delta$ max \\
$(\mathrm{mm})$
\end{tabular}} & \multicolumn{4}{|c|}{ 7.2節 } & \multicolumn{4}{|c|}{ 7.5節 } \\
\hline & & & $\begin{array}{l}\mathrm{jNu} \\
(\mathrm{kN})\end{array}$ & $\begin{array}{c}\text { Emax } \\
j \mathrm{Nu}\end{array}$ & $\begin{array}{l}\mathrm{jNu} \\
(\mathrm{kN})\end{array}$ & $\begin{array}{l}\mathrm{Pmax} \\
\mathrm{jNu}\end{array}$ & $\begin{array}{l}\text { cjNu } \\
(\mathrm{kN})\end{array}$ & $\begin{array}{l}\mathrm{Emax} \\
\mathrm{cjNu}\end{array}$ & $\begin{array}{l}\mathrm{cjNu}{ }^{\prime} \\
(\mathrm{kN})\end{array}$ & $\begin{array}{l}\mathrm{Emax}_{\max } \\
\mathrm{cjNu^{ \prime }}\end{array}$ \\
\hline BOF2S1 & 1281 & 0.55 & 1322 & 0.97 & 1216 & 1.05 & 696 & 1.84 & 553 & 2.31 \\
\hline BOF1S1 & 846 & 0.64 & 898 & 0.94 & 805 & 1.05 & 486 & 1.74 & 392 & 2.16 \\
\hline BOF2S2 & 1644 & 5.41 & 1795 & 0.92 & 1610 & 1.02 & 972 & 1.69 & 784 & 2.10 \\
\hline BOF1S2 & 1337 & 0.97 & 1370 & 0.98 & 1185 & 1.13 & 762 & 1.75 & 574 & 2.33 \\
\hline \multicolumn{3}{|c|}{ 均 } & & 0.95 & & 1.06 & & 1.76 & & 2.22 \\
\hline
\end{tabular}

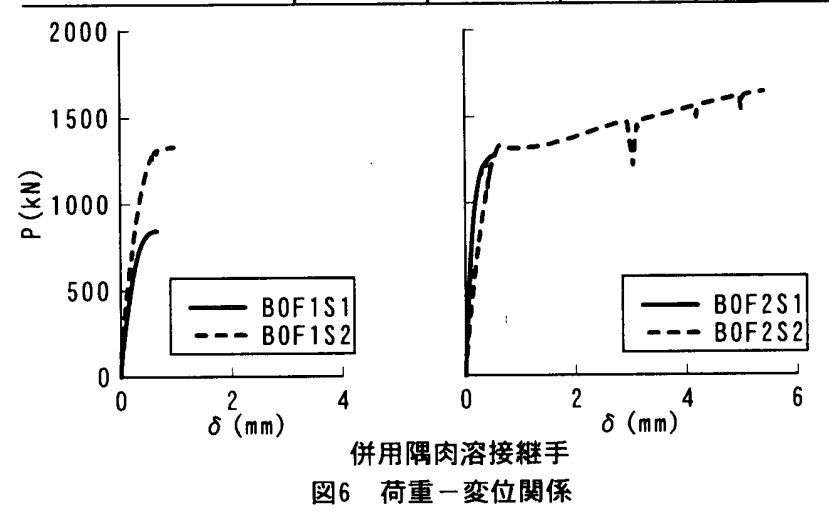



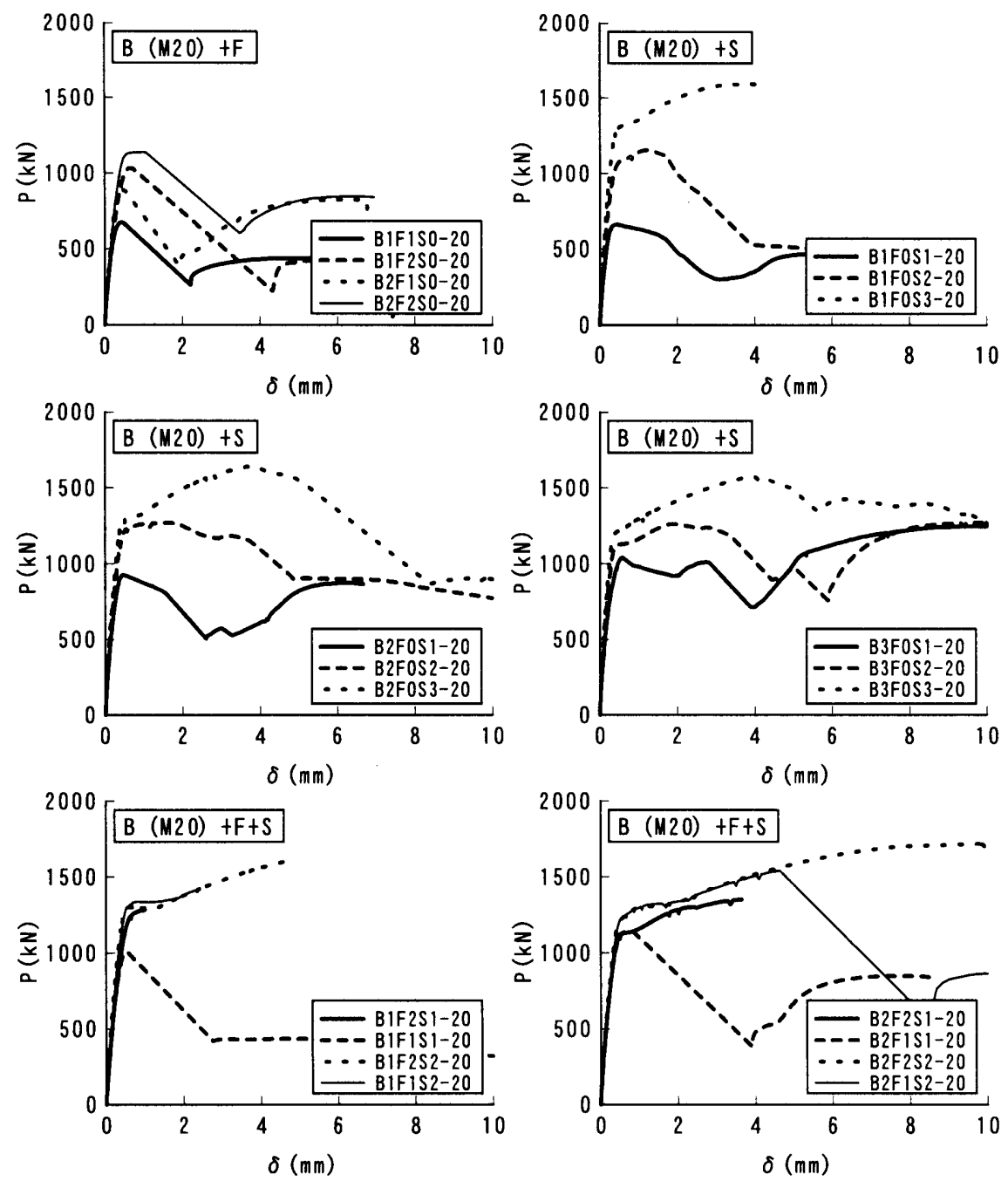

図7 荷重一変形関係 (高カボルト (M20)と隅肉浴接の併用継手)

表13-(c) 実験結果及び考察結果一覧

《高力ボルト+前面隅肉溶接+側面隅肉溶接》

\begin{tabular}{|c|c|c|c|c|c|c|c|c|c|c|}
\hline \multirow{3}{*}{ 話検体名称 } & \multicolumn{2}{|c|}{ 实駼結果 } & \multicolumn{8}{|c|}{ 考察結果 } \\
\hline & \multirow{2}{*}{\begin{tabular}{|c|} 
耐力 \\
$P_{\max }$ \\
$(\mathrm{kN})$ \\
\end{tabular}} & \multirow{2}{*}{$\begin{array}{c}\text { 変形量 } \\
\delta \text { max } \\
(\mathrm{mm})\end{array}$} & \multicolumn{4}{|c|}{ 7.4節 } & \multicolumn{4}{|c|}{ 7.5節 } \\
\hline & & & $\begin{array}{l}\mathrm{N} u \\
(\mathrm{kN})\end{array}$ & $\begin{array}{l}\mathrm{Pmax} \\
\mathrm{jNu}\end{array}$ & $\begin{array}{l}\mathrm{jNu} \\
(\mathrm{kN})\end{array}$ & $\begin{array}{l}\text { Emax } \\
\text { jNu' }\end{array}$ & $\begin{array}{l}\mathrm{cjNu} \\
(\mathrm{kN})\end{array}$ & $\begin{array}{l}\text { Pmax } \\
\text { cjNu }\end{array}$ & $\begin{array}{l}\mathrm{cjNu}^{\prime} \\
(\mathrm{kN})\end{array}$ & $\begin{array}{l}\mathrm{Pmax} \\
\mathrm{cjNu^{ \prime }}\end{array}$ \\
\hline B1F2S1-16 & 1298 & 0.75 & 1486 & 0.87 & 1380 & 0.94 & 790 & 1.64 & 647 & 2.01 \\
\hline B1F1S1-16 & 1007 & 0.63 & 1062 & 0.95 & 969 & 1.04 & 580 & 1.74 & 486 & 2.07 \\
\hline $\mathrm{B} 1 \mathrm{~F} 2 \mathrm{~S} 2-16$ & 1691 & 5.84 & 1959 & 0.86 & 1774 & 0.95 & 1066 & 1.59 & 878 & 1.93 \\
\hline B1F1S2-16 & 1408 & 2.32 & 1535 & 0.92 & 1350 & 1.04 & 856 & 1.65 & 668 & 2.11 \\
\hline B2F2S1-16 & 1342 & 2.55 & 1650 & 0.81 & 1544 & 0.87 & 883 & 1.52 & 740 & 1.81 \\
\hline B2F1S1-16 & 1099 & 0.65 & 1226 & 0.90 & 1133 & 0.97 & 673 & 1.63 & 579 & 1.90 \\
\hline B2F2S2-16 & 1696 & 7.32 & 2123 & 0.80 & 1938 & 0.88 & 1159 & 1.46 & 971 & 1.75 \\
\hline $\mathrm{B} 2 \mathrm{~F} 1 \mathrm{~S} 2-16$ & 1530 & 4.11 & 1699 & 0.90 & 1514 & 1.01 & 949 & 1.61 & 761 & 2.01 \\
\hline B1F2S1-20 & 1288 & 1.07 & 1560 & 0.83 & 1454 & 0.89 & 842 & 1.53 & 699 & 1.84 \\
\hline B1F1S1-20 & 1017 & 0.55 & 1136 & 0.90 & 1043 & 0.98 & 632 & 1.61 & 538 & 1.89 \\
\hline B1F2S2-20 & 1627 & 4.90 & 2033 & 0.80 & 1848 & 0.88 & 1118 & 1.46 & 930 & 1.75 \\
\hline B1F1S2-20 & 1424 & 2.39 & 1609 & 0.89 & 1424 & 1.00 & 908 & 1.57 & 720 & 1.98 \\
\hline $\mathrm{B} 2 \mathrm{~F} 2 \mathrm{~S} 1-20$ & 1359 & 3.72 & 1798 & 0.76 & 1692 & 0.80 & 987 & 1.38 & 844 & 1.61 \\
\hline$B 2 F 1 S 1-20$ & 1150 & 0.72 & 1374 & 0.84 & 1281 & 0.90 & 777 & 1.48 & 683 & 1.68 \\
\hline $\mathrm{B} 2 \mathrm{~F} 2 \mathrm{~S} 2-20$ & 1717 & 9.86 & 2271 & 0.76 & 2086 & 0.82 & 1263 & 1.36 & 1076 & 1.60 \\
\hline $\mathrm{B} 2 \mathrm{~F} 1 \mathrm{~S} 2-20$ & 1541 & 4.64 & 1847 & 0.83 & 1662 & 0.93 & 1053 & 1.46 & 865 & 1.78 \\
\hline B1F2S1-H & 1320 & 1.07 & 1570 & 0.84 & 1464 & 0.90 & 842 & 1.57 & 699 & 1.89 \\
\hline B1F2S2-H & 1728 & 4.90 & 2043 & 0.85 & 1858 & 0.93 & 1118 & 1.55 & 930 & 1.86 \\
\hline B2F2S2-H & 1744 & 9.86 & 2290 & 0.76 & 2106 & 0.83 & 1263 & 1.38 & 1076 & 1.62 \\
\hline & & 0.84 & & 0.92 & & 1.54 & & 1.85 \\
\hline
\end{tabular}

表13-(a) 実験結果及び考察結果一覧

《高力ボルト+前面隅肉溶接》

\begin{tabular}{|c|c|c|c|c|c|c|}
\hline \multirow{3}{*}{ 試験体名称 } & \multicolumn{2}{|c|}{ 英験轺果 } & \multicolumn{4}{|c|}{ 考察結果 } \\
\hline & \multirow{2}{*}{\begin{tabular}{|c|} 
耐力 \\
$P_{\max }$ \\
$(\mathrm{kN})$ \\
\end{tabular}} & \multirow{2}{*}{$\begin{array}{l}\text { 变形贵 } \\
\delta \text { max } \\
(\mathrm{mm})\end{array}$} & \multicolumn{2}{|c|}{ 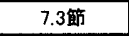 } & \multicolumn{2}{|c|}{ 7.5節 } \\
\hline & & & $\begin{array}{l}\mathrm{jNu} \\
(\mathrm{kN})\end{array}$ & $\begin{array}{c}\text { Emax } \\
\text { jNu }\end{array}$ & $\begin{array}{l}\mathrm{cjNu} \\
(\mathrm{kN})\end{array}$ & $\begin{array}{l}\text { Pmax } \\
\text { cjNu }\end{array}$ \\
\hline B1F1S0-16 & 529 & 0.36 & 589 & 0.90 & 304 & 1.74 \\
\hline $\mathrm{B} 1 \mathrm{~F} 2 \mathrm{SO}-16$ & 912 & 0.60 & 1013 & 0.90 & 514 & 1.78 \\
\hline $\mathrm{B} 2 \mathrm{~F} 1 \mathrm{~S} 0-16$ & 768 & 0.24 & 753 & 1.02 & 397 & 1.94 \\
\hline B2F2SO-16 & 1119 & 0.69 & 1178 & \begin{tabular}{|l|}
0.95 \\
\end{tabular} & 607 & 1.84 \\
\hline B1FISO-20 & 672 & 0.43 & 663 & 1.01 & 356 & 1.89 \\
\hline $\mathrm{B} 1 \mathrm{~F} 2 \mathrm{SO}-20$ & 1036 & 0.65 & 1087 & 0.95 & 566 & 1.83 \\
\hline B2F1SO-20 & 894 & 0.44 & 901 & 0.99 & 501 & 1.78 \\
\hline $\mathrm{B} 2 \mathrm{~F} 2 \mathrm{SO}-20$ & 1141 & 0.97 & 1326 & 0.86 & 711 & 1.60 \\
\hline \multicolumn{3}{|c|}{ 平均值 } & & 0.95 & & 1.80 \\
\hline
\end{tabular}

表13-(b) 実験結果及び考察結果一覧

《高力ボルト+側面隅肉溶接》

\begin{tabular}{|c|c|c|c|c|c|c|}
\hline \multirow{3}{*}{ 試轺体名称 } & \multicolumn{2}{|c|}{ 実験結果 } & \multicolumn{4}{|c|}{ 考察結果 } \\
\hline & \multirow{2}{*}{$\begin{array}{l}\text { 耐力 } \\
\text { max } \\
(\mathrm{kN})\end{array}$} & \multirow{2}{*}{$\begin{array}{l}\text { 変形量 } \\
\delta \mathrm{max} \\
(\mathrm{mm})\end{array}$} & \multicolumn{2}{|c|}{ 7.3節 } & \multicolumn{2}{|c|}{ 7.5節 } \\
\hline & & & $\begin{array}{l}\mathrm{jNu} \\
(\mathrm{kN})\end{array}$ & $\frac{P_{\max }}{j \mathrm{Nu}}$ & $\begin{array}{l}\mathrm{cjNu} \\
(\mathrm{kN})\end{array}$ & $\frac{P_{\max }}{\mathrm{cjNu}^{2}}$ \\
\hline B1FOS1-16 & 602 & 0.53 & 637 & 0.94 & 370 & 1.63 \\
\hline B1FOS2-16 & \begin{tabular}{|l|}
1005 \\
\end{tabular} & 0.69 & 1110 & 0.91 & 646 & 1.56 \\
\hline B1F0S3-16 & 1570 & 3.37 & 1583 & 0.99 & 922 & 1.70 \\
\hline B2FOS $1-16$ & 771 & 0.54 & 801 & 0.96 & 463 & 1.67 \\
\hline B2F0S2-16 & \begin{tabular}{|l|}
1199 \\
\end{tabular} & 0.85 & 1274 & 0.94 & 739 & 1.62 \\
\hline B2FOS3-16 & 1564 & 2.87 & 1747 & 0.90 & 1015 & 1.54 \\
\hline B3FOS1-16 & 980 & 1.17 & 965 & 1.02 & 557 & 1.76 \\
\hline B3FOS2-16 & \begin{tabular}{|l|}
1400 \\
\end{tabular} & 4.17 & 1438 & 0.97 & 833 & 1.68 \\
\hline B3FOS3-16 & 1666 & 4.86 & 1911 & 0.87 & 1109 & 1.50 \\
\hline B1FOS1-20 & 668 & 0.42 & 711 & 0.94 & 422 & 1.59 \\
\hline B1FOS2-20 & 1167 & 1.20 & 1184 & 0.99 & 698 & \begin{tabular}{|l|}
1.67 \\
\end{tabular} \\
\hline B1FOS3-20 & 1606 & 3.96 & 1657 & 0.97 & 974 & 1.65 \\
\hline B2FOS1-20 & 928 & 0.49 & 949 & 0.98 & 567 & \begin{tabular}{|l}
1.64 \\
\end{tabular} \\
\hline B2FOS2-20 & 1269 & 1.58 & 1422 & 0.89 & 843 & 1.51 \\
\hline B2FOS3-20 & 1654 & 3.86 & 1895 & 0.87 & 1119 & 1.48 \\
\hline B3FOS1-20 & 1041 & 10.39 & 1187 & 0.88 & 713 & 1.46 \\
\hline B3FOS2-20 & 1267 & 9.60 & 1660 & 0.76 & 989 & 1.28 \\
\hline B3F0S3-20 & 1577 & 4.01 & 2133 & 0.74 & 1265 & 1.25 \\
\hline B1F0S1-H & 691 & 0.40 & 721 & 0.96 & 422 & \begin{tabular}{|l}
1.64 \\
\end{tabular} \\
\hline B1F0S2-H & 1131 & 0.90 & 1193 & 0.95 & 698 & 1.62 \\
\hline B2F0S1-H & 880 & 0.47 & 968 & 0.91 & 567 & 1.55 \\
\hline B2FOS2-H & 1266 & 0.95 & 1441 & 0.88 & 843 & 1.50 \\
\hline B3FOS2-H & 1462 & 6.01 & 1689 & 0.87 & 989 & 1.48 \\
\hline \multicolumn{3}{|c|}{ 平均値 } & & 0.92 & & 1.56 \\
\hline
\end{tabular}

表 14 被接合材降伏荷重

\begin{tabular}{|c|c|c|c|c|}
\hline & & $\begin{array}{c}\text { 全断面 } \\
\text { 降伏耐力 } \\
(\mathrm{kN})\end{array}$ & $\begin{array}{c}\text { M16ボルトモ } \\
\text { 欠損部降伏的力 } \\
(\mathrm{kN})\end{array}$ & $\begin{array}{c}\text { M20ボルト孔 } \\
\text { 欠損部㦀伏䙳力 } \\
\text { (kN) }\end{array}$ \\
\hline 添板 & 2-PL19 & 1477 & 1211 & 1152 \\
\hline 母材 & PL25 & 1553 & 1353 & 1309 \\
\hline
\end{tabular}

挙動は最大耐力が弾性限界のすぐ後に生じているものと、弾性限界 を示した後に明膫な降伏現象が生じ、3〜 5 mm程度の塑性変形を生じ た後に最大耐力を示すものに大別される。

後者での、降伏現象はほぼ $1300 \mathrm{kN}$ 程度で生じている。これは表 14 に示すボル卜孔欠損部有効断面の降伏荷重より明らかなようにこの 降状現象は添板が降伏したことによるものと考えられる。ただし、 このボルトれ欠損部における降伏耐力は高力ボルトによる材間圧縮 力の存在、隅肉溶接が併用されていることの影響から表14に示すボ ルト孔欠損部の降伏荷重よりかなり大きくなり、1300kN程度となつ たものと考えられる。

図 2 に見られるように、隅肉溶接のみの試験体では降伏現象が明 膫に認められるものは少なく、かつ最大耐力を示すまでの変形量は 
$0.6 \sim 1.2 \mathrm{~mm}$ 程度と極めて小さい值である。一方、高力ボルト接合部 では、 $0.2 \mathrm{~mm}$ 前後ですべりが発生し、その後 $1 \sim 2 \mathrm{~mm}$ 程度のすべりを 生じて支圧状態となり、その後 $5 、 6 \mathrm{~mm}$ 程度の変形を生じて最大耐力 に達する。このような隅肉溶接の変形量と高力ボルトのすべり量の 対応から考えて高力ボルトと隅肉溶接の併用継手の耐力評価では、 高力ボルトについてすべり耐力を基本とし、隅肉溶接については最 大耐力を基本とすることが妥当であると考えられ、この点は文献1） と変りはない。

\section{2 并用隅肉溶接繶手}

併用隅肉溶接継手の最大耐力の評価には、二つの考え方がある。 第 1 の考え方は、前面隅肉溶接、側面隅肉溶接とも単体としての最 大耐力を単純に累加する方法であり、その場合最大耐力は下式で表 される。

$\mathrm{jNu}=\mathrm{Pfu}+\mathrm{Psu}$

第 2 の考え方は、前面隅肉溶接と側面隅肉溶接の各単独継目の耐 カのバランスによって前面隅肉溶接が最大耐力に至り、側面隅肉溶 接が降伏耐力である場合之、側面隅肉溶接が最大耐力に至り、前面 隅肉溶接が降伏耐力である場合を考えたものである。この最大耐力 は下式で表される。

$j u^{\prime}=\min (P f u+P s y, P f y+P s u)$

Pfu、Pfy : 前面隅肉溶接継目の最大耐力および降伏耐力実験値 $(\mathrm{kN})$ Psu、Psy：側面隅肉溶接継目の最大耐力および降伏耐力実験値 $(\mathrm{kN})$ このように各接合要素の耐力を累加した耐力を累加耐力 $(\mathrm{jNu})$ と呼 び、最大耐力の実験值を累加耐力で除した值を累加効率 $(\mathrm{Pmax} / \mathrm{j} \mathrm{Nu})$ と呼ぶこととする。(3)、(4) 式による累加耐力 $\mathrm{jNu} 、 \mathrm{jNu}$ およびこれ らに対する累加効率を表 12 にまとめた。

以上のような検討の結果、併用隅肉溶接継手の累加効率は、前面 隅肉溶接継目、側面隅肉溶接継目それぞれの最大耐力を単純累加し た場合 $0.92 \sim 0.98$ 、平均値 0.95 程度であり、第 2 の考え方による 場合は、1.02〜1.13、平均 1.06 となっている。後者の方が安全側の 評価となっていることは当然のことではあるが、併用隅肉溶接継手 については(3) 式と (4) 式のどちらを採用しても累加効率の平均值は $\pm 5 \%$ 以内の評価ができる。

\section{3 高力ボルトと前面隅肉溶接または側面隅肉溶接との併用継手}

高力ボルトと前面隅肉溶接または側面隅肉溶接との併用継手に関 する実験結果および考察結果を、表 13 (a)、(b)に示す。この表には、
高力ボルトのすべり耐力とそれぞれの溶接継目の最大耐力の和によ る累加耐力 $(\mathrm{jNu})$ および累加効率 $(\mathrm{Pmax} / \mathrm{jNu})$ を示した。

$\mathrm{jNu}=\mathrm{Pbs}+\mathrm{Pfu}+\mathrm{Psu}$

$\mathrm{Pbs}$ : 高力ボルトのすべり耐力 $(\mathrm{kN})$

高力ボルトと前面隅肉溶接の併用継手における、累加効率は $0.86 \sim 1.02$ 、平均 0.95 であり、高力ボルトと側面隅肉溶接の併用継 手においては、0.74〜 1.02、平均 0.92 である。累加効率 $\mathrm{Pmax} / \mathrm{j} \mathrm{Nu}$ を縦軸に、jNu/Peyを横軸にとって両者の関係を示したのが図8であ る。ここでPeyは素材試験結果を用いた添板のボルト孔欠損部降伏 耐力計算值である。

図8を見ると累加効率は、 jNu/Peyが増加すると低下する傾向が認 められる。Peyは添板のボルト孔欠損を考慮した降伏耐力であり、こ の値が高力ボルトのすべり耐力に影響を与えていると考えられるが、 この種の併用継手では有効断面の降伏耐力は隅肉溶接を併用した影 響で多少上昇すると考えられ、その影響が j N u/Pey が大きくなる場 合に現れたものと考えられる。

各試験体における上述の添板の有効断面の降伏の影響を考え、以 後の考察においても併用継手の耐力を図によって検討する場合、統 一的に横軸は検討する耐力をPeyで除したものを用いることとする。

\section{4 高力ボルトと前面隅肉溶接および側面隅肉溶接との併用链手}

高力ボルトと前面隅肉溶接および側面隅肉溶接との併用継手につ いて、隅肉溶接継目の耐力時における接合部の変形の適合条件を考 慮しない場合と、考慮した場合について、7.2節と同様に二つの考え 方による検討を行う。前者の考え方による累加耐力 $(\mathrm{j} \mathrm{Nu})$ と後者の考 え方による累加耐力 ( j Nu') およびそれぞれの累加効率を表13(c)にま 之め、併用継手が最大耐力に至るまでに添板の有効断面の降伏現象 が起きていることを考慮して $\mathrm{Pmax} / \mathrm{jNu}$ と j Nu/Pey の関係を図 9 に、 Pmax/jNu’ と jNu'/Pey の関係を図 10 に示す。

j Nu' $=$ Pbs + min (Pfu + Psy, Pfy + Psu)

前者の考え方による場合の累加効率は、 $0.76 \sim 0.95$ 、平均值 0.84 であり、後者の考え方による場合の累加効率は $0.80 \sim 1.04$ 、平 均 0.92 である。

併用隅肉溶接、高力ボルトと前面隅肉溶接のみ、高力ボルトと側 面隅肉溶接のみの場合に比べ、高力ボルトと前面および側面隅肉溶 接の 3 つが併用された場合の累加効率が低下しているが、これは累 加耐力にこれら 3 つの接合要素の変形の適合性が考慮されていない ためと考えられる。この点を考慮した累加耐力 $\mathrm{jNu}$ が、この点を考

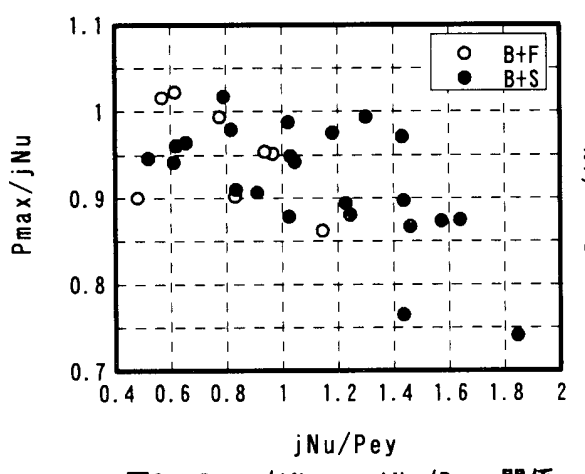

图8 Pmax/jNu - jNu/Pey 関係

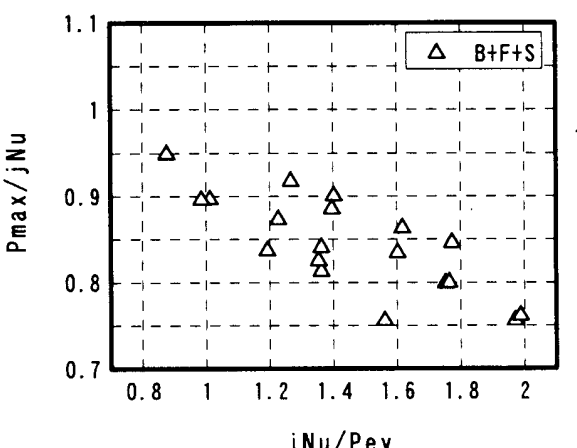

図9 $P_{\max } / \mathrm{jNu}-j \mathrm{Nu} / \mathrm{Pey}$ 関係

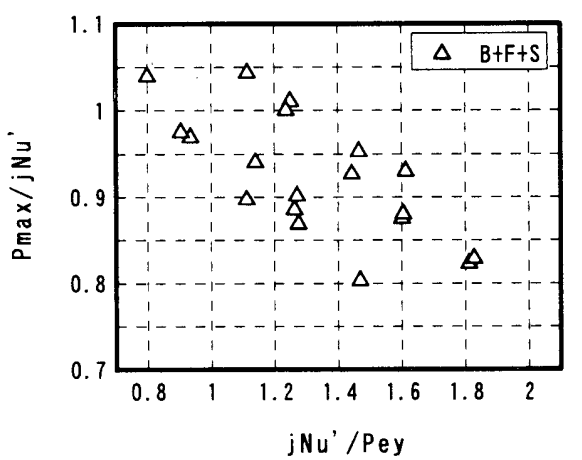

図10 Pmax/jNu' - jNu'/Pey 関係 
慮していない累加耐力 $\mathrm{jNu} よ り$ 累加効率が高いのはそのことを裏付 けていることになる。

図9.10より $\mathrm{jNu} 、 \mathrm{jNu}$ についての累加効率はともに $\mathrm{j}$ Nu、 $\mathrm{jNu}$ 'を Pey で除した值が増加するとほぼ直線的に低下している。これは 7.3 節で述べたように添板の有効断面の降伏の影響によるものであ る。

\section{5 公称酎力に対する安全率の検讨}

以上の最大耐力に関する実験結果の検討より、接合部の最大耐力 を評価するには、高力ボルトはすべり耐力で評価し、隅肉溶接継目 に関しては前面隅肉溶接または側面隅肉溶接単独の場合はそれらの 最大耐力で評価すればよいが、前面隅肉溶接と側面隅肉溶接の両方 を組み合わせて用いる場合は、両者の最大耐力の単純累加とする評 価と(4) 式による最大耐力を用いる評価があることを示した。以下、 このような考え方に基づいて最大耐力の公称值を算定した場合につ いて、実験值がどの程度の安全率を有しているかを検討する。ただ し、この場合の隅肉溶接の最大耐力の公称値として、5.2.2で述べた 今回の試験体における隅肉溶接の過大な耐力上昇の影響を除いて考 えるため、実験で得られた最大耐力上昇係数の平均值を「鋼構造限 界状態設計指針・同解説」3)に示された過去の実験による平均值で除 した值、すなわち前面隅肉溶接継手については $3.09 / 2.06=1.50$ 、側 面隅肉溶接継手については $1.85 / 1.35=1.38$ を乗じることとする。

併用継手の公称耐力 ( $\mathrm{cju}$ ) は (7)、(8) 式で求め、接合要素の公称耐 力は以下に示す算定式を用いる。降伏耐力計算值 cPfy、cPsyはcPfu、 $\mathrm{cPsu}$ の最大耐力計算式の $\sigma$ uを $\sigma \mathrm{y}$ に置き換えて算出したものであ る。公称耐力と最大耐力実験值を公称耐力で除した安全率を表 12 、 13 にまとめた。Pmax/cjNuとcjNu/Peyの関係を図11 1 に、Pmax/cjNu' と cjNu'/Peyの関係を図 12 に示す。
$\mathrm{cjNu}=\mathrm{cPbs}+\mathrm{cPfu}+\mathrm{cPsu}$

cjNu' $=c P b s+\min (c P f u+c P s y, c P f y+c P s u)$

$$
\begin{aligned}
& \mathrm{cPbs}=\mathrm{n} \cdot \mathrm{m} \cdot \mu \cdot \mathrm{Ni} \\
& \mathrm{cPfu}=1.50(1.4 \mathrm{Af} \cdot \sigma \mathrm{u} / \sqrt{3}) \\
& \mathrm{cPfu}=1.38(1.0 \mathrm{As} \cdot \sigma \mathrm{u} / \sqrt{3})
\end{aligned}
$$

$\mathrm{cPbs}$ : 高力ボルトのすべり耐力計算值 $(\mathrm{kN})$

cPfy, cPfu:前面隅肉溶接継目の降伏耐力および最大耐力計算值 $(\mathrm{kN})$ cPsy, cPsu: 側面隅肉溶接継目の降伏耐力および最大耐力計算值 $(\mathrm{kN})$ $\mathrm{n}:$ ボルト本数

\section{$\mathrm{m}$ : せん断面の数}

$\mu:$ すべり係数 $=0.45$

$\mathrm{Ni}$ : 設計ボルト張力 $\mathrm{M} 16=104(\mathrm{kN}) 、 \mathrm{M} 20=162(\mathrm{kN})$

Af : 前面隅肉溶接の理論のど断面積 $\left(\mathrm{cm}^{2}\right)$

As : 側面隅肉溶接の理論のど断面積 $\left(\mathrm{cm}^{2}\right)$

$\sigma \mathrm{u}:$ 被接合材の引張強さ $=490\left(\mathrm{~N} / \mathrm{mm}^{2}\right)$

公称耐力に対する最大耐力の安全率は高力ボルトと前面隅肉溶接 の併用継手においては $1.74 \sim 1.94$ で平均 1.80 、高力ボルトと側面 隅肉溶接の併用継手においては $1.25 \sim 1.76$ で平均 1.56 である。上 記の算定式は高力ボルトと前面隅肉溶接または側面隅肉溶接との併 用継手についていずれも十分安全側の評価となっている。高力ボル トと前面隅肉溶接および側面隅肉溶接の併用継手においては、Pmax/ $\mathrm{cjNu}$ は $1.36 \sim 1.74$ で平均 $1.54 、 \mathrm{Pmax} / \mathrm{cj} \mathrm{Nu}$ 'は $1.60 \sim 2.11$ で平均 1.85である。(7)式による評価より(8)式による評価の方が安全側であ るが、どちらの評価方法においても実験值に対しては十分安全側の 評価である。この評価結果を(7) 式による場合と (8)式による場合に 分けて高力ボルトと前面隅肉溶接または側面隅肉溶接の併用継手の 評価結果と共に図示したものが図11、12である。(7)式を採用した場 合、併用継手 $(B+F+S)$ のmax/cjNuは併用継手 $(B+F 、 B+S)$ のmax/cj Nu

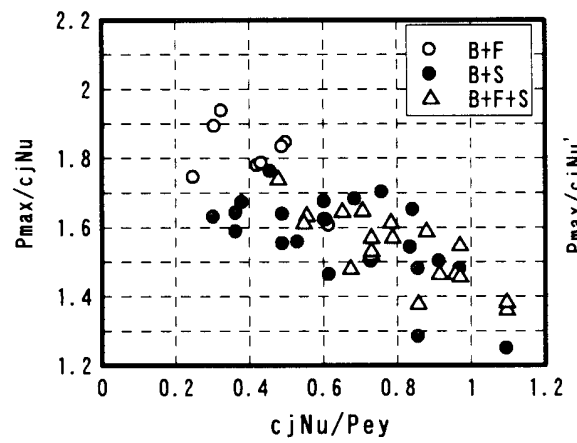

图11 Pmax/cjNu - cjNu/Pey関係

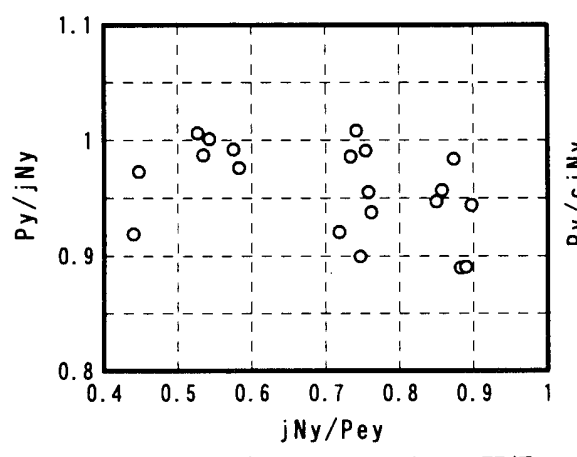

図13 Py/jNy - jNy/Pey 関係

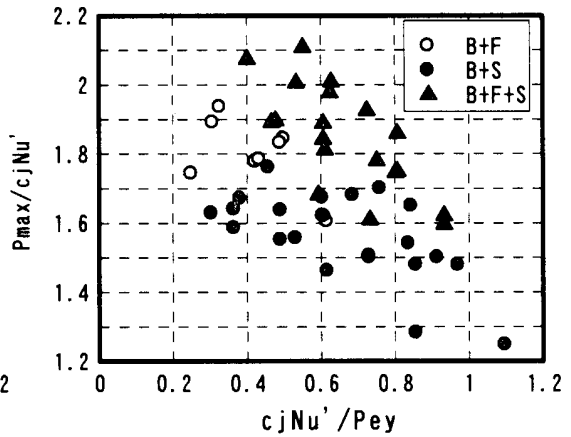

图12 $P \max / \mathrm{cjNu} u^{\prime}-c j N u^{\prime} / P$ ey関係

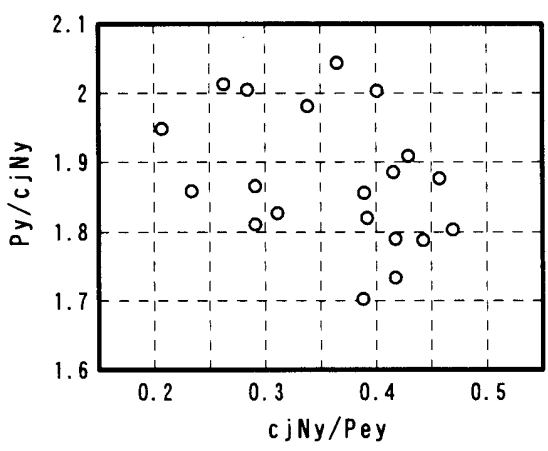

\begin{tabular}{|c|c|c|c|c|c|c|}
\hline \multirow{3}{*}{ 試験体名称 } & \multicolumn{2}{|c|}{ 実呀結果 } & \multicolumn{4}{|c|}{ 考察結果 } \\
\hline & \multirow{2}{*}{$\begin{array}{l}\text { 耐力 } \\
\mathrm{Py} \\
(\mathrm{kN})\end{array}$} & \multirow{2}{*}{ 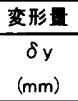 } & \multicolumn{2}{|c|}{7.6 .1 節 } & \multicolumn{2}{|c|}{ 7.6.2節 } \\
\hline & & & $\begin{array}{l}\text { jNy } \\
(\mathrm{kN})\end{array}$ & $\begin{array}{l}\mathrm{By} \\
\mathrm{jNy}\end{array}$ & $\begin{array}{l}\mathrm{cjNy} \\
(\mathrm{kNN})\end{array}$ & $\underset{c j N y}{\mathrm{By}}$ \\
\hline B1F1S0-16 & 492 & 0.24 & 536 & 0.92 & 253 & 1.95 \\
\hline B1F2S0-16 & 815 & 0.38 & 907 & 0.90 & 412 & 1.98 \\
\hline B2F1S0-16 & 693 & 0.14 & 700 & 0.99 & 346 & 2.00 \\
\hline $\mathrm{B} 2 \mathrm{~F} 2 \mathrm{SO}-16$ & 952 & 0.36 & 1071 & 0.89 & 505 & 1.88 \\
\hline B1FOS1-16 & 529 & 0.23 & 545 & 0.97 & 285 & 1.86 \\
\hline B1F0S2-16 & 866 & 0.25 & 925 & 0.94 & 476 & 1.82 \\
\hline B2FOS1-16 & 691 & 0.27 & 709 & 0.97 & 378 & 1.83 \\
\hline B2FOS2-16 & 1027 & 0.37 & 1089 & 0.94 & 570 & 1.80 \\
\hline B3F0S1-16 & 803 & 0.25 & 873 & 0.92 & 472 & 1.70 \\
\hline B1F1S1-16 & 907 & 0.39 & 916 & 0.99 & 444 & 2.04 \\
\hline B2F1S1-16 & 960 & 0.36 & 1080 & 0.89 & 538 & 1.79 \\
\hline B1F1S0-20 & 613 & 0.27 & 610 & 1.00 & 305 & 2.01 \\
\hline B1F2SO-20 & 928 & 0.43 & 981 & 0.95 & 464 & 2.00 \\
\hline B2F1SO-20 & 835 & 0.31 & 848 & 0.98 & 450 & 1.85 \\
\hline BIFOS $1-20$ & 610 & 0.25 & 619 & 0.99 & 337 & 1.81 \\
\hline B2F0S $1-20$ & 863 & 0.34 & 857 & 1.01 & 483 & 1.79 \\
\hline B1F1S1-20 & 946 & 0.40 & 990 & 0.96 & 496 & 1.91 \\
\hline B1F0S1-H & 628 & 0.25 & 628 & 1.00 & 337 & 1.86 \\
\hline B1FOS2-H & 991 & 0.40 & 1008 & 0.98 & 528 & 1.87 \\
\hline B2FOS1-H & 835 & 0.34 & 876 & 0.95 & 483 & 1.73 \\
\hline \multicolumn{3}{|c|}{ 平均値 } & & 0.96 & & 1.87 \\
\hline
\end{tabular}

図14 Py/cjNy - cjNy/Pey 関係
表15 降伏耐カについて . 
と同程度の値となり、全体としてのばらつきも小さい。しかし、(8) 式を採用した場合、併用継手 $(B+F+S) の P \max / \mathrm{c} \mathrm{j} \mathrm{Nu}$ 'は併用継手 $(B+F$ 、 $\mathrm{B}+\mathrm{S}$ ) のPmax/cjNu'より高い值となり、全体としてのばらつきも大き い。また、(8) 式は (7) 式に比べ全体的に過小評価の程度が大きいこと が判る。従って、高力ボルトと前面隅肉溶接および側面隅肉溶接の 併用継手においては(7)式による最大耐力の評価式を用いることが妥 当であると考えられる。

\section{6 降伏耐力の検封}

以上、併用継手の最大耐力について検討してきたが、次に継手の 降伏耐力について検討する。継手の降伏耐力の実験值 (Py) は荷重変 形関係において接線剛性が初期剛性の $1 / 3$ になるときの荷重を基本 とし、荷重変形関係で明らかな剛性低下が認められるものについて はその值とする。なお、ここでは降伏耐力 (Py)に添板の有効断面の 降伏現象の影響があると考えられる試験体についてはこれを除外し て検討する。即ち、M16 を使用したものについては Pmax $<1211 \mathrm{kN}$ 、 M20を使用したものについてはPmax $<1152 \mathrm{kN}$ となる試験体について 検討を行う。

\subsection{1 実䀫值に関する検封}

降伏耐力の累加耐力 ( $\mathrm{jNy}$ ) は前面隅肉溶接継目および側面隅肉溶接 継目の降伏耐力と高力ボルトのすべり耐力を累加したものとする。 $\mathrm{j} N y$ と jNyで降伏耐力の実験值 (Py) を除した降伏耐力の累加効率を表 15 にまとめ、Py/jNy と j Ny/Peyの関係を図 13 に示す。降伏耐力の累 加効率は $0.89 \sim 1.01$ で、平均 0.96 である。従って、併用継手の降 伏耐力は各接合要素の降伏耐力を単純に累加した值の $95 \%$ 程度であ ると考えられ、この值は最大耐力の場合とほぼ同等である。

\subsection{2 公称耐力に対する安全率}

併用継手の降伏耐力実験值に対する公称耐力 ( c j Ny) の評価を行う。 隅肉溶接の降伏耐力の計算值については(7)式において溶着部の引張 強さを降伏強さに置き換えて算定する。また、降伏耐力上昇係数は 7.5 節で述べた内容と同様に補正した值を使用する。即ち、図 4 より 降伏耐力上昇係数は「鋼構造限界状態設計指針・同解説」における 最大耐力上昇係数に近い值になることが確認されたため、ここでも 前面隅肉溶接継手については 2.06、側面隅肉溶接継手については 1.35 を基準とし、前面隅肉溶接継手については $3.55 / 2.06=1.72$ 、 側面隅肉溶接継手については1.96/1.35=1.45を公称值に乗じるこ ととする。cjNy およびPy/cjNy を表 15 にまとめ、Py/cjNy とcjNy/ Pey の関係を図 14 に示す。公称耐力に対する降伏耐力実験值の安全 率は 1.70 〜 2.04 で、平均 1.87 であり、最大耐力についての安全率 と比べ幾分大きいことが判る。

\section{8. まとめ}

本論文では高力ボルト摩擦面の表面処理法としてグリットブラス 卜処理を行い、炭酸ガスシールドアーク溶接による隅肉溶接を用い た併用継手の力学性状を確認するため一連の実験を行い、主として 併用継手の最大耐力に関する評価を行った。

本実験で採用した隅肉溶接継目は、隅肉溶接のサイズが接合する 鋼材の板厚に比べ極端に小さかったため、その最大耐力は公称値に 対し非常に大きいものであった。しかし、その点を考慮した検討に よって、隅肉溶接を用いた併用継手の最大耐力の評価は適正に行う
ことができた。本実験において得られた主要な結果をまとめると以 下のようになる。

1) 前面隅肉溶接と側面隅肉溶接を併用した継手では、その最大耐力 は両者の変形性能の違いをある程度考慮した場合の評価式 ( (4) 式) と両者の最大耐力を単純に累加した場合の評価式((3) 式)では 累加効率として約 $10 \%$ 程度の差があるがその差はあまり大きなも のではない。7.2節の検討結果から (4) 式の評価式は必ずしも前面 隅肉溶接部と側面隅肉溶接部の変形性能を適切に評価していると はいえず、やや安全側すぎると考えられる。一方 (3) 式の評価式を 採用した場合でも公称值を用いた場合の最大耐力実験值に対する 安全率は十分あるので、設計式の単純化を考え併用隅肉溶接継手 の最大耐力の評価式として (3) 式の評価式を採用して問題はないと 考えられる。

2)高力ボルトと隅肉溶接の併用継手の最大耐力は高力ボルトのすべ り耐力と隅肉溶接継目の最大耐力の累加耐力で適切に評価できる。 また、文献1）と本研究では高力ボルトの強度レベル、摩擦面の表 面処理方法、溶接継目の力学性能などが若干異なっている点があ るが、その場合でも文献1)の耐力評価と同じ考え方に基づいた評 価方法によって妥当な評価が可能である。従って、併用継手を構 成する高力ボルトおよび隅肉溶接それぞれの接合要素の力学挙動 が本論文と同様である併用継手について同じ耐力評価方法を採用 できると考えられる。

3)設計で用いる高力ボルトと隅肉溶接の併用継手の降伏耐力設計式 は、上記最大耐力評価式の隅肉溶接の引張強さを降伏強さに置き 換えたものとした場合、実験值に対して十分な安全率を有してお り、設計上十分実用的である。

4）併用継手とする場合、高力ボルトを1本又は2本しか用いない場合 でも、そのはしあき寸法は鋼構造設計規準に示された規定值であ る2.5d (d:ボルト径)よりかなり小さく本実験のように1.25dとし ても構造上問題はない。

\section{参孝文献}

1)併用䋛手小委員会 : 各種ファスナーの併用継手に関する実験的研究(その 1)、(その2) 日本建築学会論文報告集第161 号、1969.7 第166 号1970.11 2）日本建築学会 : 高力ボルト接合設計施工指針、1993

3）日本建築学会：領構造限界状態設計指針・同解説、1998

4) 伂 威雄、加藤 勉、森田耕次: 溶接継手の耐力一すみ肉溶接継手の終局 耐力一、日本建築学会論文報告集第 146 号、1968.4

5) 加藤 勉：すみ肉溶接継手の耐力に関する研究、日本建築学会論文報告集 第 75 号、 1962.8

6) 鶴田 明、持田貞一：すみ肉溶接の静的強度に関する研究、日本建築学会論 文報管集第69号、1961.10

7)森田耕次、江波戸和正、田中浩史、里見孝之：部分溶込溶接継目のせ九断 挙動に関する実験的研究、蔧造工学論文集 Vol.38B、1992.3

(2000年 7 月 4 日原稿受理，2000年12月 8 日採用決定） 